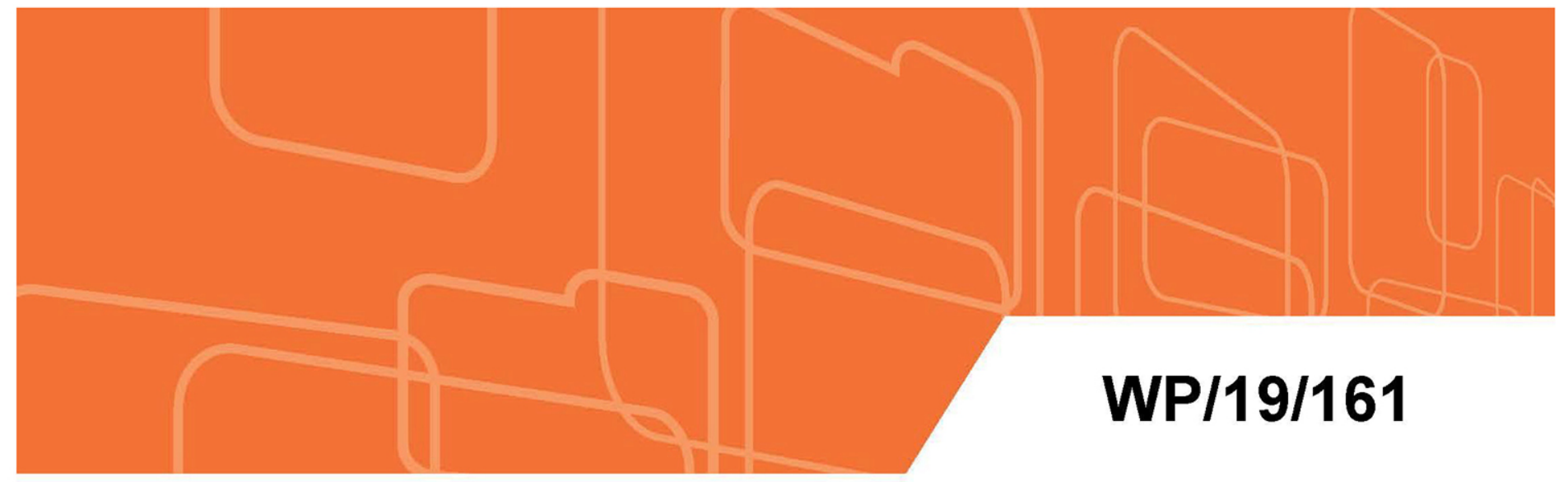

IMF Working Paper

\title{
Do Old Habits Die Hard? \\ Central Banks and the Bretton Woods Gold Puzzle
}

by Eric Monnet and Damien Puy

IMF Working Papers describe research in progress by the author(s) and are published to elicit comments and to encourage debate. The views expressed in IMF Working Papers are those of the author(s) and do not necessarily represent the views of the IMF, its Executive Board, or IMF management.

I N T E R N A T I O N 


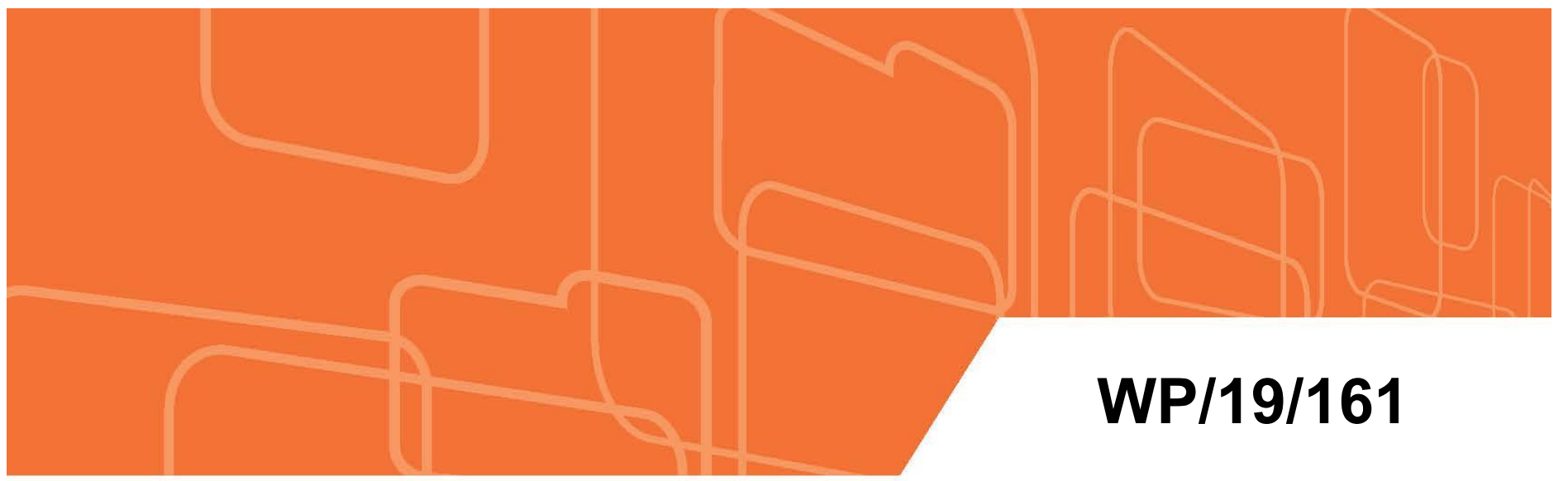

\section{IMF Working Paper}

\section{Do Old Habits Die Hard? \\ Central Banks and the Bretton Woods Gold Puzzle}

by Eric Monnet and Damien Puy

IMF Working Papers describe research in progress by the author(s) and are published to elicit comments and to encourage debate. The views expressed in IMF Working Papers are those of the author(s) and do not necessarily represent the views of the IMF, its Executive Board, or IMF management.

I N T E R N A T I O N A L M O N E T A R Y 


\title{
IMF Working Paper
}

\author{
Research Department
}

\section{Do Old Habits Die Hard? Central Banks and the Bretton Woods Gold Puzzle \\ Prepared by Eric Monnet and Damien Puy}

Authorized for distribution by Maria Soledad Martinez Peria

July 2019

IMF Working Papers describe research in progress by the author(s) and are published to elicit comments and to encourage debate. The views expressed in IMF Working Papers are those of the author(s) and do not necessarily represent the views of the IMF, its Executive Board, or IMF management.

\begin{abstract}
Why did monetary authorities hold large gold reserves under Bretton Woods (1944-1971) when only the US had to? We argue that gold holdings were driven by institutional memory and persistent habits of central bankers. Countries continued to back currency in circulation with gold reserves, following rules of the pre-WWII gold standard. The longer an institution spent in the gold standard (and the older the policymakers), the stronger the correlation between gold reserves and currency. Since dollars and gold were not perfect substitutes, the Bretton Woods system never worked as expected. Even after radical institutional change, history still shapes the decisions of policymakers.
\end{abstract}

JEL Classification Numbers: D8, E5, F5, F55, M14, N1

Keywords: Bretton Woods, gold, foreign reserves, gold standard, culture, central banks

Authors’ E-Mail Addresses: eric.monnet@banque-france.fr; dpuy@imf.org.

\footnotetext{
${ }^{1}$ The views expressed in this paper are those of the authors and do not represent the views of the IMF, the Banque de France or the Eurosystem. We thank seminar participants at the Banque de France, EHES conference in Pisa, EHS conference in Cambridge, ASSA meetings in San Francisco, London School of Economics, Paris School of Economics, University Paris 1, University of Geneva, Bank of Spain, Business History conference in Baltimore, European Macro-History workshop in York and World Bank's Annual Bank Conference on Development Economics for their comments. We are grateful to Michael Bordo, Olivier Jeanne, Alain Naef, François Keslair, Pierre Sicsic, Miklos Vari, Lars Jonung, Carsten Burhop, Matthias Morys, Tobias Straumann, Peter ContiBrown, Soledad Martinez-Peria and Andrea Presbitero for useful discussions.
} 
Contents

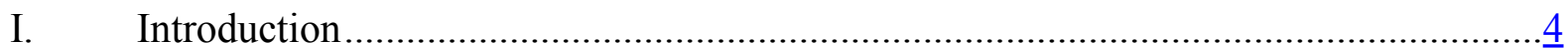

II. Gold and the Bretton Woods System .....................................................................

The Gold Puzzle................................................................................................

Potential Motives for Gold Holding .......................................................................

III. Gold and Currency Under Bretton Woods............................................................11

The Determinants of Reserves Holdings ………………......................................12

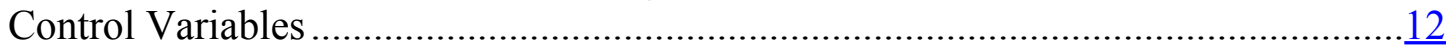

Data Sources and Sample..........................................................................13

Money rather than Trade...................................................................................

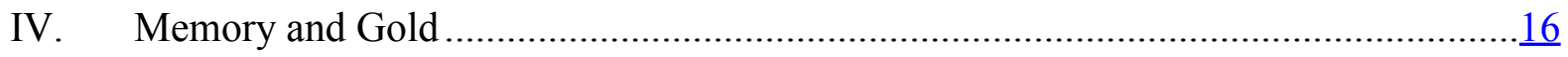

Past Exposure to the Gold Standard.......................................................................16

Personal Experience vs. Institutional Memory ……………………………………...17

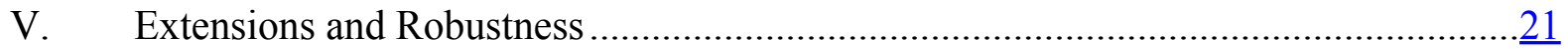

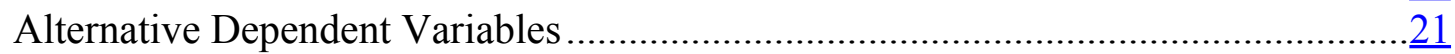

Reverse Causality and Sterilization .......................................................................

VI. Implications: New Perspectives on the Bretton Woods system.....................................23

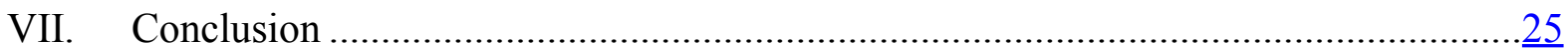

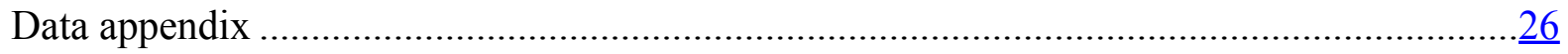

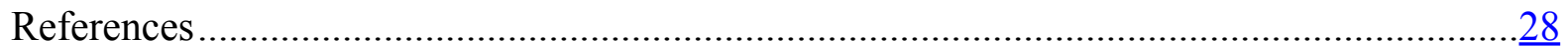

Tables

1: Gold and Currency in Circulation ………………………........................................

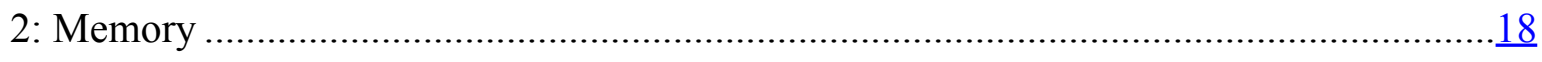

3: Personal Experience and Institutional Memory ………………………………….....

4: Determinants of Non-Gold Reserves and Share of Gold in Total Reserves .....................22

Figures

Figure 1: Gold and International Reserves, 1950-1971 (billions of US\$).............................

Figure 2; Catching-up. The Evolution of cover ratios over time (1950-1970).....................10

Figure 3: Number of Years in the Gold Standard vs. Average Age of Central Banks'

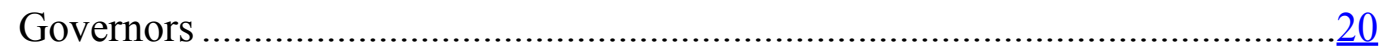

Figure 4: Currency-Gold Correlation (1950-1973) .......................................................... 


\section{Introduction}

Can the persistence of past practices and norms lead to unexpected economic policy consequences? Several recent articles in the field of behavioral economics have pointed out that past behaviors and experiences of individuals are strong determinants of their current economic practices and beliefs. $^{2}$ This literature has focused on individual decisions but also points out to institutional memory as a key area for future research. ${ }^{3}$ Can the past experience of organizations explain their current strategy or policy?

With such questions in mind, this paper studies how gold standard's practices survived among monetary authorities after the Second World War (WWII), although the aftermath of the Great Depression, the shock of the war, and the Bretton Woods agreement in 1944 were supposed to have eliminated them. ${ }^{4}$ It is well known that non-US central banks started to rebuild their gold stock after the war, a move that was largely unanticipated by the founders of the Bretton Woods system. This phenomenon, which we refer to as the Bretton Woods "gold puzzle", undermined confidence in the fixed gold-dollar exchange rate, pushed the US to suspend gold convertibility in 1971 and initiated the global transition towards a floating exchange rate regime in 1973. But although the demise of the Bretton Woods system is viewed by many as a key turning point in the history of international monetary affairs, the motivations behind the continued accumulation of gold reserves have remained somewhat of a mystery. ${ }^{5}$ Banknotes were no longer legally redeemable in gold at the central bank under Bretton Woods. Therefore, contrary to the classical (1880s-1914) and interwar gold standard, the Bretton Woods system did not impose that central banks tie their hands by backing notes issuance with gold reserves. Only the USA committed to convert dollars into gold on demand from other central banks. Moreover, since the yield on reserves in dollars (i.e. US government securities) was always positive, holding gold reserves was costly for non-US countries. So why did monetary authorities around the world hold gold?

We cast a new light on that question using a new comprehensive dataset on gold reserves and macroeconomic statistics for a large set of countries, assembled using the IMF archives. ${ }^{6} \mathrm{We}$ highlight two key findings. First, the amount of gold that countries accumulated under Bretton Woods was still connected to their domestic money supply (currency in circulation), even after

\footnotetext{
${ }^{2}$ See Bertrand and Schoar (2003), Alesina and Fuchs-Schuendeln (2007), Malmendier and Nagel (2011, 2015), Koudijs and Voth, (2016).

${ }^{3}$ See, among others, Camerer and Malmendier (2007) and Bouwman and Malmendier (2015).

${ }^{4}$ Some countries did not have a central bank, implying that the Treasury was the "monetary authority". In some countries, the management of foreign reserves was performed by the central bank on behalf of the Treasury. In the remainder of the paper, we refer interchangeably to central banks and monetary authorities.

${ }^{5}$ Kenen (1963), Machlup (1964), Gilbert (1968), Williamson (1973), Bordo \& Eichengreen (1998).

${ }^{6}$ Our sample represents, on average, 94 percent of gold reserves held outside of the United States over the Bretton Woods era.
} 
accounting for all other potential accumulation motives. Second, the intensity with which they did so was a function of their past exposure to the gold standard before WWII. Monetary authorities that had adhered to the gold standard were much more likely to back their currency in circulation under Bretton Woods than others. Even among countries which had been exposed to the gold standard, we find that the longer they had been on the gold standard before the war, the higher the correlation between their gold holdings and currency in circulation. We interpret this finding as evidence of memory shaping monetary practices. The magnitude of this "memory" effect is large: Countries that adhered to both classical and interwar gold standards continued to back between 40 percent and 50 percent of every new unit of currency issued with gold, thereby using a de facto cover ratio almost identical to those in effect during the gold standard.

We further investigate how the (old) habits of the gold standard transmitted over time and affected monetary policy decisions decades later. We explore two hypotheses. The first is that institutions themselves have a memory, which in turns pushes policymakers to behave like in the past. This "institutional memory" hypothesis is consistent with historical studies that have shown the importance of a gold standard culture in interwar central banks (Eichengreen \& Temin 2000, Mouré 2002) and, more generally, the importance of corporate culture and history for the making of monetary policy (James 1985, Capie 2010, Schenk 2010, Straumann 2010, Monnet 2018a). ${ }^{7}$ The second - the "individual memory" hypothesis - is that the personal experience of central bankers or governors matters (Romer \& Romer 2004, Malmendier et al. 2017, Bordo \& Istrefi 2018, Mishra \& Reshef 2019). In that case, an older central banker is more likely to behave as if in the gold standard simply because his formative years happened during that period. Think, for example, about governors in place in the early 1950's but born in the 1880s or 1890s (as in Germany, Austria, Mexico, Switzerland or Belgium). They are old enough to remember the stability of the pre-WWI gold standard and were likely to be involved during the attempts at restoring the gold standard in the 1920s. For them, the failure of the gold standard in the early 1930s looked like the exception, rather than the norm. By contrast, the central bankers born in the 1910s (Greece, Finland, Norway, Sweden) either never worked under the gold standard or had their first professional experience when the interwar gold standard was collapsing. They are less likely to associate the gold standard with periods of economic stability and to look at gold for an anchor of monetary policy.

Using new data on the identity and age of governors of central banks to proxy for "individual memory", we find that personal experience of governors mattered for gold accumulation. Central banks with an older governor were more prone to back currency in circulation with gold. More importantly, this "individual memory" effect does not disappear when confronted with proxies of "institutional memory". When the sample is restricted to gold standard countries, the age of the governor dominates the number of years spent in the gold standard. These

\footnotetext{
${ }^{7}$ Corporate culture, which is close to what Camerer and Malmendier (2007) call "corporate repairs", is a familiar concept to business historians (Lipartito 1995, Rowlinson and Procter 1999) who have studied the transmission of norms within an organization over time.
} 
results suggest an independent (and strong) effect of personal experience in addition to the effect of corporate or institutional culture.

Our paper contributes to three different literatures. First, to our knowledge, we are the first to explore, in a rigorous manner, the determinants of reserve holdings (gold or foreign exchange) between 1950 and 1970. Contemporary studies of foreign reserve holdings conducted in the 1960s and 1970s were based on limited statistical evidence and very short samples. In contrast, recent historical studies on international reserves holdings do not include data on Bretton Woods and start in the late 1970s. This paper bridges this gap and, in doing so, challenges the conventional wisdom regarding reserves accumulation during Bretton Woods. In particular, our findings clearly show that reserves accumulation in that period was not purely "trade-based"; a common starting point in the literature (Williamson 1973, Obstfeld et al. 2010).

Second, this paper provides new evidence on the macroeconomic effects of corporate culture and individual experience of policymakers. The persistence of gold standard practices is consistent with behavioral models arguing that decision makers do not consider all the information available to them but overemphasize the information garnered from their personal experience (Gennaioli \& Schleifer 2010). In search of an anchor, central bankers under Bretton Woods overemphasized the extent to which gold reserves guaranteed the soundness of domestic money (Kriz, 1959). From a behavioral finance perspective (e.g. Malmendier and Nagel 2011, 2015; Koudijs and Voth 2016), it means that the portfolio of central banks was shaped by experience rather than by rational financial arbitrage between gold and other foreign exchange reserves (mostly US Treasury bills). It is also consistent with empirical findings on the role of the personal experience of leaders on organizational outcomes - as emphasized by Bertrand and Schoar (2003), Malmendier et al. (2011), Benmelech \& Frydman (2015) for CEOs of corporations, and by Romer \& Romer (2004), Malmendier et al. (2017) and Bordo \& Istrefi (2018) for board members of the US Federal Reserve System. Our results support the role of personal experience in shaping macroeconomic policy and highlight its implications for the functioning of the international monetary system. We also distinguish the experience of the policymakers from the history of the organization itself, showing that both can matter and have a separate effect.

Finally, this paper has important implications for the literature on the design of the international monetary system. Our results are especially connected to recent studies discussing the historical (and current) role of a safe reserve asset. ${ }^{8}$ Writing during the Bretton Woods period, some prominent economists considered the possibility that central banks would tie domestic money to gold reserves but they quickly dismissed this hypothesis on the basis that such practices,

\footnotetext{
${ }^{8}$ See for instance Eichengreen, Mehl and Chitu (2017), Farhi and Maggiori (2017), Bordo et al. (2017), Bordo and McCauley (2018), Gourinchas et al. (2019). Our argument is different from Bordo and Eichengreen (1998) and Eichengreen et al. (2017) who highlight autocorrelation in the level of gold and other international reserves in the XXth century. Our main result is not about pathdependency of the level of the gold stock itself but about the persistence of the practice to back currency by gold reserves.
} 
inherited from the gold standard, would have been "naïve, obsolete and primitive" (Machlup, 1966, p.190-191) or "an irrational act based on traditional superstitions" (Williamson, 1973, p.689). ${ }^{9}$ Contemporaries showed too much optimism about the disappearance of old habits. Memory clearly prevented the Bretton Woods system to function as its founders expected; a point we discuss further in Section VI.

The remainder of this paper is organized as follows. Section II reviews the Bretton Woods system, its difference with respect to the pre-WWII gold standards, and the puzzling resurgence of gold reserves after 1950. Section III presents the data and econometric framework as well as preliminary results regarding the positive correlation between gold reserves and currency. Section IV explores the role of institutional and personal memory. Robustness checks are performed in Section V. Section VI discusses the broader policy implications of our results. Section VII concludes.

\section{Gold and the Bretton Woods System}

The Bretton Woods System was created by the 1944 Articles of Agreement to design a new international monetary order at a multilateral conference held in Bretton Woods (USA) from July $1^{\text {st }}$ to July $22^{\text {nd }}, 1944 .{ }^{10}$ The Articles of Agreement were eventually ratified in December 1945 and the system started to be implemented after the conference of Savannah in March 1946. The new international monetary system departed from the pre-WWI gold standard and the interwar gold exchange standard in four ways (Bordo and Eichengreen 1998). First, controls on the capital and on the current accounts were officially allowed to avoid destabilizing international movements of funds. Second, the International Monetary Fund (IMF) was created to provide short-term liquidity to domestic monetary authorities when needed and conduct surveillance of national policies to avoid destabilizing balance of payments imbalances. Third, pegged exchange rate could be adjusted, under authorization by the IMF, in case of fundamental disequilibrium. Fixed exchange rates were no longer defined in terms of gold parity but in terms of dollars. Only the US dollar was defined as convertible into gold at $\$ 35$ per ounce. Fourth - and most important for the purpose of this article - gold coinage as well as the commitment of central banks (or the Treasury in countries without a central bank) to redeem banknotes in gold was abandoned everywhere in the world. ${ }^{11}$ This meant that, in principle, monetary authorities were no longer required to back currency in circulation by gold reserves in order to maintain the credibility of their currency in the eyes of the

\footnotetext{
${ }^{9}$ The full quote is "it is of course possible that countries may actually determine their reserve holdings with reference to their money supplies even if this is an irrational act based on traditional superstitions, but there is no persuasive evidence that they do." (Williamson, 1973, p.689)

10 See Bordo (1993, 2017) and James (1996) for a description of the operations and key issues of the system. See Bordo \& Eichengreen (1993), Schuler and Rosenberg (2012), Helleiner (2014) and Scott-Smith and Rofe (2017) for more detailed accounts of the conference and the subsequent events.

${ }^{11}$ Strong limits were also imposed on gold holding and gold transactions by citizens and firms. Some countries, like the US and the UK, forbade private holding of gold entirely (Kriz 1959).
} 
public. ${ }^{12}$ In some countries, the interwar gold standard had already limited the redeemability of notes at the central banks to bullion instead of coins, thus discouraging private holding of gold but without legally breaking the link between gold and money. In 1944, the Bretton Woods system finished to break that link.

Of course, gold had not been completely abandoned and remained the final means of settlement between the monetary authorities of the main trading nations. ${ }^{13}$ The United States which kept more than 90 percent of gold reserves held in the world by monetary authorities after the war - was in favor of maintaining an international role for gold but even Keynes - author of the English plan at the Bretton Woods conference - advised to "continue to use gold and its prestige as a means of settling international accounts". ${ }^{14}$ In the end, gold received only two official roles. First, the United States should be prepared to exchange gold for dollars when requested by other central banks. Second, IMF member countries could pay their subscription to IMF in gold (but this was not mandatory).

\section{The Gold Puzzle}

The secondary role of gold under the new international system was such that, outside the United States, the appropriate level of gold reserves by central banks - i.e. the level ensuring the proper functioning of the international monetary system - was never defined or even discussed at the Bretton Woods conference. In fact, since the yield on reserves in dollars (US government securities) was always positive, holding gold reserves was costly for non-US countries. ${ }^{15}$ Holding gold was neither legally necessary nor economically sensible. This situation was in sharp contrast with the classical and interwar gold standard, during which countries complied with a de facto or de jure cover ratio. The cover ratio expressed the amount of gold reserves that the central bank (or the Treasury) had to keep in its balance sheet as a function of the currency in circulation (notes and coins). The de facto ratio was often more important than de jure requirement. The latter only provided a minimum (Morys 2013), and some countries (prominently France, the main holder of gold before WWII together with the USA) did not even have a de jure cover ratio under the gold standard (Bazot, Bordo \& Monnet 2016).

\footnotetext{
${ }^{12}$ A few countries (Belgium and Switzerland) did not change their central bank statuses and maintained a legal gold cover ratio (Aufricht 1967, Bordo \& Eichengreen 1998), although there is no evidence that they were committed to respect it. They were set at 33 percent (Belgium) and 40 percent (Switzerland) of notes in circulation. Gilbert $(1968$, p. 7$)$ notes that "this legal provision is a leftover from the days gold coins were in active circulation and has little relation to present-day conditions". We will show below that other countries followed similar policies, even if they were not constrained by law.

${ }^{13}$ In practice, most of the settlements were made in foreign currencies - the dollar mostly and, to a minor extent, the pound sterling.

${ }^{14}$ Speech by Lord Keynes on the International Monetary Fund debate, May 23, 1944. Hansard Parliamentary Debates, House of Lords, 5th Series, Vol. CXXXI, Cols. 838-49.

${ }^{15}$ Based on the amount of gold held by central banks and the rate of return on T-bills between 1950 and 1971, we estimate an average opportunity cost of 0.2 percent of GDP per year per country.
} 
Although gold was dead in theory, it remained alive in practice. Looking at cross-country reserves data between 1950 and 1970, two key facts emerge. First, the total amount of gold held by foreign monetary authorities increased throughout the Bretton Woods period. Starting in the mid-1950s, the demand for gold by non-US monetary authorities began to put pressure on the US gold stock. As shown on Figure 1, this trend accelerated starting in 1958-1959 when most countries started to open their current account and make their currencies fully convertible (Bordo 1993). ${ }^{16}$

Figure 1: Gold and International Reserves, 1950-1971 (billions of US\$)

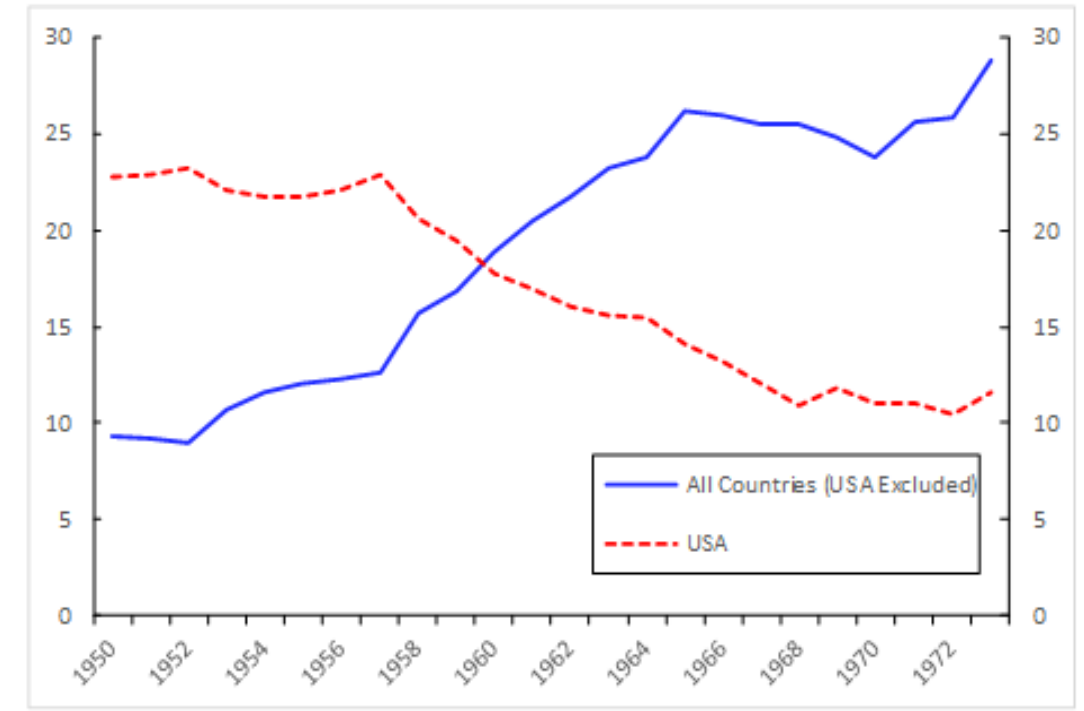

Note: The 37 non-US countries cove $94 \%$ of gold reserves held outside of the US over Bretton Woods on aver age. Country names are reported in Appendix. Source International Financial Statistics

Second, and more importantly, we find that countries that started with a lower gold ratio at the beginning of the period increased it over time. Figure 2 shows a negative relationship between the cover ratio in 1950 - when countries entered Bretton Woods - and the change in the cover ratio from 1950 to 1970 . Although some countries reduced their ratios, especially the ones that had inherited a very high ratio after the war because their gold reserves had been unaffected (Switzerland, Great Britain, Canada etc.), many kept their ratios stable. Several countries even increased their ratios, showing in fact a desire to "catch up" with the rest of the pack. Again, one should not underestimate how this simple fact runs counter to Bretton Woods' common intuition. Increasing the cover ratio or keeping it stable meant that countries had to buy gold to keep up with the unavoidable increase in their monetary base over time. If the new Bretton Woods system had

\footnotetext{
${ }^{16}$ Although central banks had little opportunity to buy gold in 1944 - except at the US gold window - it changed when the London gold market reopened in 1954 (Kriz 1959, Kenen 1963, Bordo et al. 2017). It was then easier for central banks to replenish their gold stocks if they wanted to. From the mid-1960s onwards, various mechanisms between central banks were designed to avoid a further increase in non-U.S. gold stocks (James 1996, Bordo et al. 2017). It temporarily reduced the accumulation rate of other countries (Figure 1), but ultimately proved insufficient.
} 
really stopped ancient practices, cover ratios should have decreased and converged towards very low values over the period. Figure 2 also shows the heterogeneity in the behavior of countries which had a similar cover ratio in 1950. For example, among those with a cover ratio around 50 percent in 1950, some reduced their cover ratio by more than 25 percent over 1950-1970 (Mexico, Peru, Canada, etc.) whereas other increased it (Belgium, Netherlands, Portugal). We explore the determinants of this heterogeneity in gold holdings more formally in sections III and IV.

Figure 2; Catching-up. The Evolution of cover ratios over time (1950-1970)

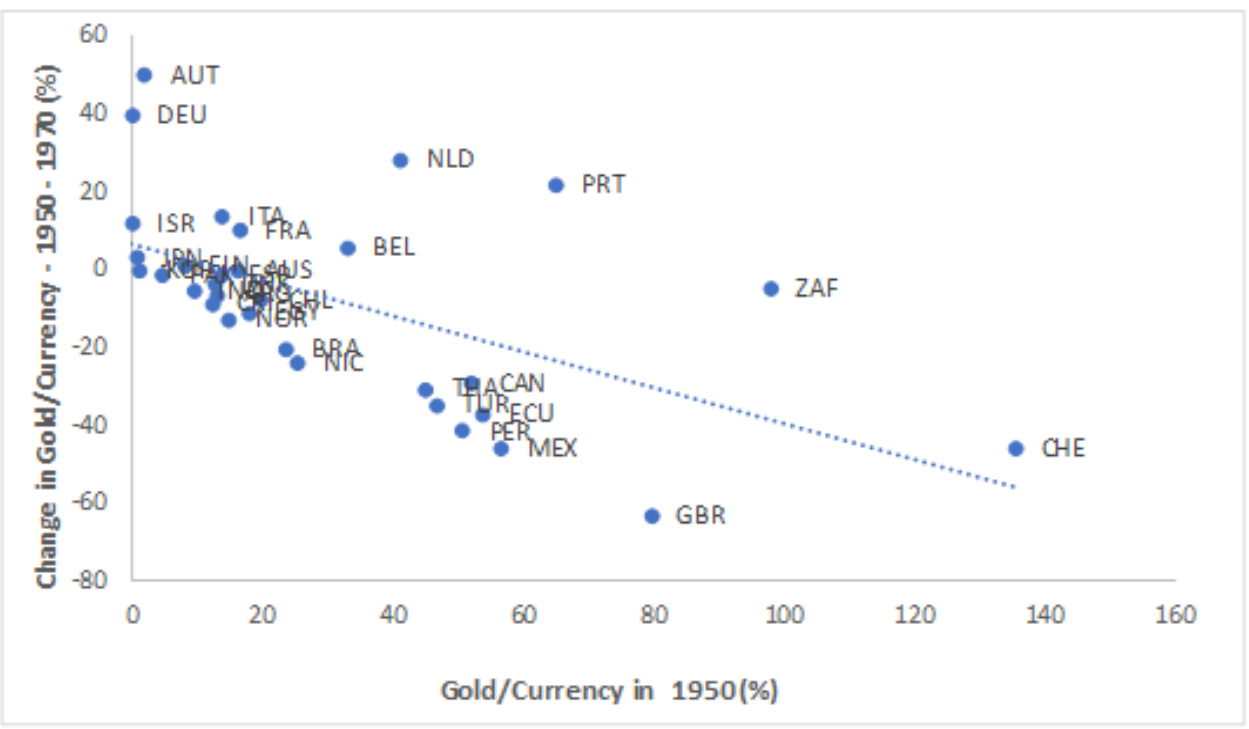

Note: Uruguay and Ireland are excluded because their cover ratios are not available in 1950 .

\section{Potential Motives for Gold Holding}

Why would monetary authorities keep accumulating gold? Some policymakers (Holtrop 1957) and bankers (Kriz 1959) suggested that a link between gold and the domestic money base survived because central bankers were in need of an anchor for monetary policy. In the uncertain postwar world, such an anchor was found in past practices: an increasing ratio of money supply to gold (or foreign exchange) reserves would indicate excessive inflationary pressures. Economists were, however, reluctant to believe in such "irrational" and "primitive" behavior (Machlup 1966, Williamson 1973). As a result, none of the quantitative studies on foreign reserves holding under Bretton Woods investigated the link between gold and domestic currency (see Grubel 1971, IMF 1971, Williamson 1973, Cohen 1975 for surveys of this literature). The most common explanation for the increase in gold holdings by other central banks was the loss of credibility of the US dollar over time, especially in the 1960s due to the increase in military spending caused by the Vietnam War and the absence of US national stabilization policies (Bordo, Monnet and Naef 2017). Expectations of a dollar devaluation pushed foreign central banks to acquire more gold to minimize the potential losses that would follow a devaluation (Kenen and Yudin 1965, Gilbert 1968, Officer 
and Willett 1969, Makin 1971). However, that explanation cannot explain the very uneven distribution and reconstruction of gold holding across countries (Figure 2). ${ }^{17}$

An alternative explanation favored by contemporary economists was that the holding of gold reserves had the same determinants as foreign exchange reserves (despite the opportunity cost of holding reserves), and in particular trade openness (Triffin 1947, 1960; Grubel 1971; Williamson 1973). If central banks could buy gold on the market and if gold was used by monetary authorities to settle transactions, trade openness would determine the accumulation of gold reserves. However, little evidence of such behavior has been presented so far. Kenen (1963) noted that only foreign exchange reserves behave as working balances and that central banks bought gold when reserves increased but did not sell gold when reserves decreased. In the 1960s, gold holdings also appeared to be driven by political motives (Gilbert 1968). France notoriously converted massive dollar holdings in gold at the US gold window in 1965-1966 to express disagreement with the dominant position of the US in the international monetary system (Bordo et al. 2017). On the opposite side, the US was using political coercion to limit the purchase of gold by Germany and Japan (Gavin 2004). ${ }^{18}$ More generally, economists and policymakers became convinced that idiosyncratic political motives were the main drivers of gold holdings. We challenge such views in the next section.

\section{Gold and Currency Under Bretton Woods}

This section formally explores the motives behind gold holdings under Bretton Woods. Past studies of foreign reserve holdings conducted in the 1960s and 1970s were based on limited statistical evidence and very short samples. ${ }^{19}$ Recent studies of foreign reserves holdings based on long samples do not include data on Bretton Woods and usually start in the late 1970 s. $^{20}$ We build on this literature for our empirical framework but apply it to reserves accumulation between 1950 and 1970.

\footnotetext{
${ }^{17}$ A very uneven reconstruction of gold holdings could be rationalized by heterogenous expectations about the possibility of a dollar devaluation. In that case however, one would still need to rationalize why central banks held very different expectations in the first place. An alternative interpretation of this paper is to explore whether history and experience shaped such expectations, which in turn favored the use of old habits.

${ }^{18}$ It led one of the most famous international economists of the times to argue that the only motive of reserve holding (both gold and foreign exchange) was to keep up with other countries and show strong political power (Machlup 1966).

19 To our knowledge and according to Williamson (1973), Courchene and Youssef (1967) is the only empirical study that documented a positive correlation between money and foreign reserves for this period. However, evidence was limited to countryby-country correlations between 1960 to 1965, and they did not discuss the hypothesis of currency in circulation being backed by gold reserves. More generally, econometric studies in that period were very limited and regressions, when used, were spurious because of unit roots.

${ }^{20}$ These studies find a correlation between the total money supply (including deposits) and total foreign reserves (Obstfeld et al. 2010) but not between the money base (currency in circulation) and reserves. Aizenman \& Inoue (2013) look at the determinants of gold reserves on the period 1979-2010 and find no correlation between gold reserves and the money supply.
} 


\section{The Determinants of Reserves Holdings}

Following the standard literature on foreign reserves (Rodrik 2006, Aizenman \& Lee 2008, Obstfeld et al. 2010), we estimate the following equation:

$$
\operatorname{Gold}_{i, t}=\alpha+d_{t}+\beta T_{i, t}+\gamma M_{i, t}+\theta Z_{i, t}+\epsilon_{i, t}
$$

where (i) Gold Git $_{\text {is }}$ the level of gold reserves divided by GDP of country $i$ in year $t$ (ii) $T_{i, t}$ denotes the trade openness - measured as exports plus imports over GDP - of country $i$ in year $t$ (iii) $M_{i, t}$ denotes the level of currency in circulation (banknotes and coins) divided by GDP and (iv) $Z_{i, t}$ represents a set of control variables to be discussed below. Finally, $d_{t}$ represents year-fixed effects and $\alpha$ a constant.

In what follows, we focus our attention on the $\gamma$ coefficient, which captures the relationship between gold and currency in circulation. As usual in the literature (e.g. Obstfeld et al. 2010), we compare a pooled panel estimation with a country-fixed effects estimation. The pooled panel is especially useful for further analysis where we try to disentangle the effects of country-specific but time-invariant variables (Section IV). Trade-based accumulation motives would result in a positive $\beta$, as shown by recent empirical and theoretical studies of foreign exchange reserves (Rodrik 2006, Aizenman \& Lee 2008, Obstfeld et al. 2010, Jeanne \& Rancière 2011, Jeanne \& Sandri 2016). Idiosyncratic political reasons for holding gold reserves would appear in the residuals rather than in any fundamental determinant of the holding of foreign exchange reserves. In contrast, a positive value of $\gamma$, of magnitude close to past cover ratios, would confirm our hypothesis that monetary authorities still behave as in the gold standard.

\section{Control Variables}

Year-fixed effects capture the potential loss of credibility of the US dollar over-time as well as the yield on foreign exchange reserves (or, put differently, the time-varying opportunity cost of holding gold). Other controls included in $Z_{i, t}$ are in line with the state-of-the-art literature on reserve holding (Rodrik 2006, Aizenman \& Lee 2008, Obstfeld et al. 2010) which has especially emphasized the importance of (i) current account and capital account openness and (ii) the exchange rate regime. We use the index of capital account liberalization of Quinn and Toyoda (2008). ${ }^{21} \mathrm{~A}$ higher index value (from 0 to 100) stands for a higher capital account openness. To account for exchange rate misalignment and current account openness, we control for current account surplus (as a percent of GDP) and the exchange rate premium. If the premium is positive,

\footnotetext{
${ }^{21}$ The index is based on coding the text of IMF's Annual Report on Exchange Arrangements and Exchange Restrictions (AREAER) since 1950. No de facto measure of capital account openness is available for this period.
} 
the exchange rate is overvalued, and a devaluation is expected. ${ }^{22}$ Another key control is the exchange rate regime. A country with a fixed exchange rate needs more international reserves to defend its peg. Although all countries, except Canada, adopted a fixed exchange rate during this period, their peg had different degrees of flexibility. We follow here the de facto classification of Reinhart and Rogoff (2004). A lower value of this variable means a harder peg. ${ }^{23} \mathrm{We}$ also control for the logarithm of population to capture potential effects of the size of the country (a proxy for political power) that would not be captured by the size of GDP. Finally, we follow Obstfeld et al. (2010) and control for other forms of money (i.e. deposits). Obstfeld et al. (2010) found that in the post-Bretton Woods period, the holdings of foreign reserves correlated with broad money (i.e. currency in circulation + deposits) but not with the money base (i.e. currency in circulation) ${ }^{24} \mathrm{By}$ contrast, our hypothesis is that, during Bretton Woods, the holding of foreign reserves correlated with currency in circulation.

\section{Data Sources and Sample}

We assemble a new cross-country database of reserves, monetary and macroeconomic statistics covering a large set of countries over the Bretton Woods period. Although individual series of reserves and money are provided by the IMF International Financial Statistics at an annual frequency, combining them is non-trivial because they are not expressed in the same unit; a complication that constrained previous research. Monetary statistics are expressed in contemporary domestic currency - which changes several times over the Bretton Woods period in some countries - whereas reserves are always expressed in current dollars. Historical GDP data, which are taken from the Penn World Table, are expressed in today's local currency. To express all nominal values in the same unit (i.e. the domestic currency of 1971) and obtain comparable ratios across countries, we tracked each change in currency denomination and official exchange rates using paper volumes of the International Financial Statistics published monthly since 1946. To our knowledge, we are the first to compile such a database for the Bretton Woods period.

A detailed presentation of sources and construction of variables is presented in the data appendix. The quality of monetary statistics is uneven in the first years of operation of the Bretton Woods system and nominal GDP are available for a limited number of countries in the aftermath of the war. For this reason, our sample starts in 1950. Our data set ends in 1970. We do not include

\footnotetext{
22 The premium is the difference between the official exchange rate and the black-market exchange rate in New York (data from Reinhart and Rogoff (2004)). Such an undervaluation can be motivated by mercantilist purposes, with the exchange rate kept undervalued to promote exports (Aizenman and Lee 2008).

${ }^{23}$ The index is a de facto measure which captures how much flexibility was allowed by multiple exchange rates. Under the Bretton Woods period, only Canada managed a free float for several years. Other countries had to maintain their peg within a 2 percent band. But several countries had multiple exchange rates, especially in the 1950s.

${ }^{24}$ They interpret the first result as evidence of the buffer function of foreign reserves in a globalized world (protecting the domestic banking system against sudden capital outflows), and the second result as the absence of currency board (where monetary authority would back currency in circulation by foreign exchange reserves).
} 
the year 1971 because end of the year data would include the reaction of countries to the closure of the US gold window - the de facto end of the Bretton Woods system - in August 1971. We managed to obtain comprehensive data for 38 countries. On average, these countries account for 94 percent of gold reserves held outside of the United States over the period. Table A.1 in the Appendix present the sample of countries and descriptive statistics.

Besides macroeconomic and financial statistics, we also compile several indicators to measure past exposure of central bankers and central banks to the gold standard (to be used in section III), namely (i) the number of years spent by a country in the gold standard (ii) the number of delegates at the Bretton Woods conference and (iii) the age of governors heading central banks over the Bretton Woods period. Measures of central bank past exposure to the gold standard adherence to the classical or interwar gold standard or - as a robustness check - number of years in the gold standard - are taken from Officer (2008), Wandschneider (2008), and Mitchener \& Weidenmier (2015). The number of delegates per country at the Bretton Woods conference is available in the transcripts of the conference published in Schuler \& Rosenberg (2012). We used a more detailed list established by Schuler \& Bernkopf (2014).

Data on the age of the governor of the central bank was obtained using a two-step process. We first look for the name of the ruling governor or president of the central bank for every year in our sample. This information is usually available on the websites of the central banks. Second, we look for the biographies of these governors and their birth dates. When the information is not available on the website of the central bank, we use various sources, such as regional or national Who's Who, monographs on the history of the central banks, Wikipedia or genealogical websites containing sufficient biographical information. In total, the age of the governor was found for 85 percent of our sample (i.e. country-year observations). ${ }^{25}$

\section{Money rather than Trade}

Our first result is that the amount of currency in circulation and gold reserves are strongly positively correlated (Table 1). Without controls, we estimate $\gamma$ around 0.5 (Table 1, column 1). The coefficient on trade $(\beta)$ is lower and becomes insignificant once we add standard controls (Table 1, column 2). In addition, all other control variables have the expected signs (Table 1, columns $2 \& 3$ ). Countries accumulate more reserves when they have a larger current account surplus and an undervalued exchange rate (see Aizenman \& Lee 2008), when their exchange rates are less flexible (see Obstfeld et al. 2010), when they are more financially open (Rodrik 2006). Like international reserves in general (and despite the opportunity cost to hold them), gold reserves serve as a buffer against international financial shocks and exchange rate depreciation.

\footnotetext{
25 Building a database on central bank governors post-1970, Mishra and Reshef (2019) also experienced difficulties to find biographical information. In many cases, only the name of the governor is available. Biographical information was especially difficult to find in politically unstable countries where the governors of central banks changed almost every year. The information is also missing for some years in the few countries which did not have a central bank in the 1950s.
} 
The significance and size of the currency coefficient is also confirmed when introducing country fixed-effects (Table 1, column 3). This is not the case for the coefficient on deposits which turns out small and insignificant. The amount of within variation explained by the currency variable is sizeable (0.22), suggesting that the connection between currency in circulation and gold reserves is not only explained by differences across countries, which are more likely to be driven by unobserved heterogeneity. Overall, these preliminary results contrast sharply with the results of Obstfeld et al. (2010) over the post-Bretton Woods period, which show that only deposits are positively associated with foreign reserves. It also shows that reserve accumulation during Bretton Woods was not purely "trade-based"; a common starting point in the literature (Williamson 1973, Obstfeld et al. 2010). Although this is the case for foreign exchange reserves, this is not the case for gold. ${ }^{26}$ More importantly, the size of the $\gamma$ coefficient carries a nice interpretation. We estimate it to be around 0.35 (between 0.27 and 0.43 ), which implies that 35 percent of an additional unit of currency was backed by gold reserves. In the gold standard, the average cover ratio (i.e. the ratio of gold reserves to currency in circulation) was around 40 percent, depending on the period and countries included in the sample (Bordo \& Eichengreen 1998, Morys 2013).

Table 1: Gold and Currency in Circulation

\begin{tabular}{|c|c|c|c|}
\hline VARIABLES & $(1)$ & $(2)$ & $(3)$ \\
\hline Trade & $\begin{array}{l}0.0517^{\star \star \star} \\
(0.00681)\end{array}$ & $\begin{array}{c}-0.0151 \\
(0.0102)\end{array}$ & $\begin{array}{r}-0.00292 \\
(0.0258)\end{array}$ \\
\hline Currency & $\begin{array}{l}0.506^{* \star *} \\
(0.0530)\end{array}$ & $\begin{array}{l}0.426^{\star * \star} \\
(0.0376)\end{array}$ & $\begin{array}{l}0.271^{\star} \\
(0.154)\end{array}$ \\
\hline Deposits & & $\begin{array}{l}0.243^{\star * \star} \\
(0.0228)\end{array}$ & $\begin{array}{c}0.0101 \\
(0.0672)\end{array}$ \\
\hline Exchange Rate Premium & & $\begin{array}{l}-0.0918 \\
(0.131)\end{array}$ & $\begin{array}{r}-0.0620 \\
(0.133)\end{array}$ \\
\hline Capital Account Openness & & $\begin{array}{l}0.0353^{\star \star \star} \\
(0.00521)\end{array}$ & $\begin{array}{c}0.0169^{\star} \\
(0.00959)\end{array}$ \\
\hline Currert Accourt Openness & & $\begin{array}{c}0.0997^{\star \star \star *} \\
(0.0268)\end{array}$ & $\begin{array}{c}0.0280 \\
(0.0380)\end{array}$ \\
\hline FX Flexibility & & $\begin{array}{l}-0.121^{\star \star \star *} \\
(0.0253)\end{array}$ & $\begin{array}{l}-0.0571^{*} \\
(0.0330)\end{array}$ \\
\hline Population & & $\begin{array}{c}-0.874^{\star * \star} \\
(0.132)\end{array}$ & $\begin{array}{l}-0.244 \\
(2.437)\end{array}$ \\
\hline Country FE & No & No & Yes \\
\hline Time FE & Yes & Yes & Yes \\
\hline Observations & 729 & 729 & 729 \\
\hline R-squared & 0.355 & 0.580 & 0.217 \\
\hline
\end{tabular}

Note : P-value in parentheses. ${ }^{* * *},{ }^{* *},{ }^{*}$ denote signific ance at the $1 \%, 5 \%, 10 \%$ levels. Resuts are based on Equation (1) in the text Columns (1) and (2) display the results of pooled panel estimations. Year-fixed effects are included in all estimations. Column (3) includes country-fixed effects, with standard errors clustered at the country level. The R-square reported in column (3) reports only the within variation explained by the variables of interest.

\footnotetext{
${ }^{26}$ This result is reported in Section V, where we explore the determinants of non-gold reserves.
} 


\section{Memory and Gold}

\section{Past Exposure to the Gold Standard}

The literature in behavioral economics has shown that the financial decisions of individuals are shaped by previous experience (Malmendier and Nagel 2011, 2015, Koudijs and Voth 2016). We test whether similar mechanisms can be observed for central banks' attitude towards gold. Our hypothesis is that countries that have been more exposed to the gold standard norms and practices before the Second World War were more likely to follow the gold standard rule of backing their currency by gold reserves during Bretton Woods. To test this hypothesis, we first use a variation of equation (1) and interact the variable "currency in circulation" with a variable capturing exposure to gold standard practices. We estimate the following model:

$$
\operatorname{Gold}_{i, t}=\alpha+d_{t}+\beta T_{i, t}+\gamma M_{i, t}+\theta Z_{i, t}+\delta G S_{i}+\tau\left(G S_{i} * M_{i, t}\right)+\epsilon_{i, t}
$$

Where all variables have the same definition as in (1). $G S_{i}$ captures the exposure to previous periods of gold standard. As a start, we impose that GS takes the value 1 if a country has been in both the classical gold standard (1880s-1913) and the interwar gold standard (1920s-1936), and zero otherwise. This definition is consistent with the fact that we want to capture full exposure to gold standard norms and practices. As the interwar gold standard was chaotic and of short duration - most countries left following England in 1931 and the average length was 6 years (Wandschneider 2008) -, it is unlikely that the gold standard's norms were fully integrated during this period in countries which had not been in the classical gold standard before. If a country had been on the classical gold standard (before the First World War) but had not joined again in the inter-war period, there are some reasons to believe that the gold standard's culture had no longer prevailed. ${ }^{27}$ Given that the variable GS is fixed over time within a country, we use a pooled panel estimator, and focus attention on $\tau$.

Table 2 summarizes our key result. In column (1), the interaction term $\tau$ is positive and significant, implying that backing gold reserves was more pervasive in countries that had been fully exposed to the gold standard before the Second World War. The size of the coefficient (slightly below 0.5 ) is also in line with the cover ratios of the gold standard. On the other hand, although countries outside the gold standard also backed their currency with gold, the intensity with which they do so is much smaller (around 0.16 ). ${ }^{28}$ Table 2 also reports two important results.

\footnotetext{
${ }^{27}$ We set the gold standard variable to zero for countries that were not independent before WWII (i.e. colonies and British dominions), since they did not have full political sovereignty under the gold standard and did not experience as much continuity in their political system and administration (which is key to our memory hypothesis). However, our results are not sensitive to this assumption. When, for dominions and colonies, we set the gold standard variable to be equal to the one of the colonizing country, we find a slightly lower coefficient on the interaction term ( 0.44 against 0.48 in column 1 , Table 2$)$, but the significance is unchanged.

${ }^{28}$ The coefficient attached to the gold standard variable (un-interacted) is negative. This captures the fact that, all else equal, gold standard countries had, on average, less gold than others at the start of Bretton Woods. This is mainly due to the large depletion of gold reserves during the war.
} 
First, we find that the attitude towards gold varies not only between countries in and out of the gold standard, but also across gold standard countries (Column 2). Restricting attention to countries that spent at least one year in the gold standard, we estimate equation (2) using the number of years spent in the gold standard as a measure of exposure to norms and practices of the past. We find that the intensity of the exposure to the gold standard matters for post-WWII behavior. Quantitatively, the coefficient on the interaction term (0.01) implies that roughly 20 percent of an extra unit of currency would be covered by gold in Peru (a country that spent 17 years in the gold standard) against 44 percent in Portugal (a country that spent 37 years in the gold standard).

We also perform a "falsification test" of our memory hypothesis using the number of delegates of each country at the 1944 Bretton Woods conference (Column 3). In opposition to our proxy of "gold standard exposure", this measure can be interpreted as a "Bretton Woods exposure". Countries with a higher number of delegates at the Bretton Woods conference were more active in the design of the new postwar system and its thinking, which was in complete opposition to the gold standard mentality. ${ }^{29}$ In fact, as emphasized by Helleiner (2014) and contributions in ScottSmith and Rofe (2017), emerging countries from Latin America, Africa and Middle East played a central role at the conference, with a large number of delegates, hoping that the conference would lead to a new order. By contrast, Continental European countries and Japan - long time adherents to the gold standard and key players of the prewar monetary system - were mostly absent because of the war. Column 3 shows that the interaction term between currency and the number of delegates at the Bretton Woods conference is negative. Countries which had been more involved in the design of Bretton Woods were therefore less likely to behave as in the gold standard.

\section{Personal Experience vs. Institutional Memory}

Our previous results are silent on how the habits and cultural norms of the gold standard transmitted over time. One interpretation of our findings is that institutions themselves have a memory, which pushes policymakers to behave as they did in the past. This "institutional memory" hypothesis would be consistent with historical studies that have shown the importance of a gold standard culture in interwar central banks (Eichengreen \& Temin 2000, Mouré 2002) and, more generally, the importance of corporate culture and organization's history for the making of monetary policy and the choice of the exchange rate regime (James 1985, Capie 2010, Schenk 2010, Straumann 2010, Monnet 2018a).

\footnotetext{
${ }^{29}$ This reasoning does not apply to the US and the UK, the leaders of the conference. The US is, by construction, excluded from the estimation. We keep the United Kingdom in the estimations, but results are unchanged if excluded.
} 
Table 2: Memory

\begin{tabular}{|c|c|c|c|}
\hline VARIABLES & (1) & (2) & (3) \\
\hline Trade & $\begin{array}{c}-0.0277^{\star * *} \\
(0.0104)\end{array}$ & $\begin{array}{c}-0.0609^{\star * *} \\
(0.0130)\end{array}$ & $\begin{array}{c}-0.00118 \\
(0.0115)\end{array}$ \\
\hline Currency & $\begin{array}{l}0.157^{\star * *} \\
(0.0324)\end{array}$ & $\begin{array}{l}0.189^{* *} \\
(0.0884)\end{array}$ & $\begin{array}{l}0.655^{* * *} \\
(0.0726)\end{array}$ \\
\hline Gold Standard & $\begin{array}{c}-2.916^{\star * *} \\
(0.486)\end{array}$ & & $\begin{array}{c}0.736^{* * *} \\
(0.214)\end{array}$ \\
\hline Gold Standard x Currency & $\begin{array}{l}0.486^{* * *} \\
(0.0621)\end{array}$ & & \\
\hline Gold Standard (Number of Years) & & $\begin{array}{c}-0.0134 \\
(0.0181)\end{array}$ & \\
\hline Currency x Gold Standard (Number of Years) & & $\begin{array}{c}0.01 * \star * \\
(0.00245)\end{array}$ & \\
\hline Delegates & & & $\begin{array}{l}0.406^{\star * *} \\
(0.0891)\end{array}$ \\
\hline Currency $x$ Delegates & & & $\begin{array}{c}-0.0568^{* \times *} \\
(0.0121)\end{array}$ \\
\hline Country FE & No & No & No \\
\hline Time FE & Yes & Yes & Yes \\
\hline Controls & Yes & Yes & Yes \\
\hline Observations & 729 & 508 & 729 \\
\hline R-squared & 0.620 & 0.677 & 0.607 \\
\hline
\end{tabular}

Note: P-value in parentheses. ${ }^{\star \star *},{ }^{\star *},{ }^{*}$ denote significance at the $1 \%, 5 \%, 10 \%$ levels. Standard errors are clustered at the country level. Results are based on Equation (2) in the text. Year-fixed effects are included in all estimations. Control variables are the same as in Table 1. Columns (1) and (3) use the full sample. Column (2) restricts the sample to countries that spent at least one year in the gold standard.

Another possible interpretation of our results - the "individual memory" hypothesis - is that they reflect the importance of personal experience of central bankers (in the same vein as Romer \& Romer 2004, Malmendier et al. 2017, Bordo \& Istrefi 2018, Mishra \& Reshef 2019). In that case, an older central banker is more likely to behave as if it were the gold standard because his formative years happened during the that period. This possible difference in personal attitude towards gold, and its potential (independent) effect on monetary policy, is well captured by the stark contrast between Mats Lemne, the governor of the Swedish central bank in the early fifties (1951-1955), and Maurice Frère, his counterpart heading the central bank of Belgium (19441957). Although both Sweden and Belgium had spent fifty years in the gold standard before the Second World War, the average cover ratio for Sweden under Bretton Woods was 13 percent compared to 40 percent in Belgium. How did the two institutions - both heavily exposed to the gold standard in their past - diverged so much in their attitude towards gold? 
Maurice Frère, born in 1890, studied economics in Brussels under the classical gold standard (from 1908 to 1912), worked for the Belgian administration in the economic office in London, and had an important role as an economic expert working for the Belgian government and the League of Nations in the war and interwar (Wellens 1976). As such, he was a witness and active participant to the international conferences on war reparations and monetary stabilization (i.e. return to the gold standard) after the First World War, from Genoa (1922) to Lausanne (1932). In the early 1930s, Belgium was also one member of the "gold bloc", that is the few countries that remained in the gold standard even after Britain and the United States left in 1931 and 1933. Belgium devalued in 1935 and left the "gold bloc", but de facto then followed a bullion gold standard, which was abandoned only in 1940 (van der Wee 2012). Frère became the governor of the Bank of Belgium in 1944 and, as such, was a key player in the postwar monetary stabilization. Partly because of a drastic stabilization, the monetary situation of Belgium was better than that in other European countries in the late 1940s and the central bank opposed the plan of the government to devalue at the same time as other European countries in 1949. According to Maurice Frère (1960), gold reserves were enough to maintain the parity and the government pushed for the devaluation for fiscal reasons only. During these events, the Bank of Belgium clearly expressed a commitment to gold standard practices (Cassiers and Ledent 2006) and the postwar law of the central bank did not abandon the reference to a legal requirement of gold reserves equal to 30 percent of notes issue (Aufricht 1967). In many respects, Maurice Frère was a man of the gold standard.

In stark contrast, Mats Lemne was a man of Bretton Woods and the postwar order. Born in 1919, he was only five years old when Sweden returned to the gold standard in 1924 and twelve years old when Sweden left the gold standard in 1931 (Straumann et al. 2017). During the 1930s, Sweden adopted an original system of price level targeting - inspired by writings of Knut Wicksell - which was later celebrated for its modernity and flexibility (Jonung 1979, Rathke et al. 2017). Sweden had low gold reserves at that time and acquired a large stock of foreign exchange reserves in order to defend its peg while targeting a domestic objective (Rathke et al. 2017). Contrary to Belgium, the practices of the gold standard already belonged to the past when Mats Lemne became governor of the Riksbank in 1951. While, in Belgium, Maurice Frère epitomized monetary orthodoxy against reluctant governments, Mats Lemne had strong personal links with the postwar Ministry of Finance in Sweden and was appointed to implement credit policies that would be consistent with the economic objectives of the government. According to historians Larsson and Soderberg $(2017$, p.47) his appointment was "an important factor in the politicization of the Riksbank policy".

The heterogeneity in the profiles of central bankers is captured in Figure 3, which plots the (average) age of governors against the number of years spent by the institution in the gold standard. Interestingly, the correlation is flat between the two variables, suggesting that the personal experience of the governor can have explanatory power beyond the history of the central bank (as illustrated by the Belgium and Swedish cases). We test formally the "individual memory" hypothesis in Table 3. Column 1 shows the results when we use equation (2) and interact the 
average age of the governor with currency/GDP. We find a positive and significant interaction, implying that central banks with an older governor had a higher correlation between gold and currency in circulation. ${ }^{30}$ These results show that personal experience is indeed a key variable to explain the persistence of habits over time. In columns 2 and 3, we test whether the personal experience of the central bank's governor still matters when we also include the interaction of currency and gold standard exposure in the estimation. We find that both interaction terms matter (Column 2), suggesting an independent effect of personal experience (or memory) in addition to the effect of corporate culture (or institutional memory). More striking are the results in columns 3, when we consider the interaction between currency and the number of years in the gold standard and restrict the sample to countries that adhered at least a year to the gold standard. The effect of the number of years spent in the gold standard disappears, whereas the interaction of currency and the age of the governor is significant and takes a much higher value than in the previous estimations (0.052 vs 0.015$)$ in column (2). The difference of practices between countries which had been in the gold standard before World War II is better captured by the age of policymakers than by the number of years they spent in the gold standard.

\section{Figure 3: Number of Years in the Gold Standard vs. Average Age of Central Banks' Governors}

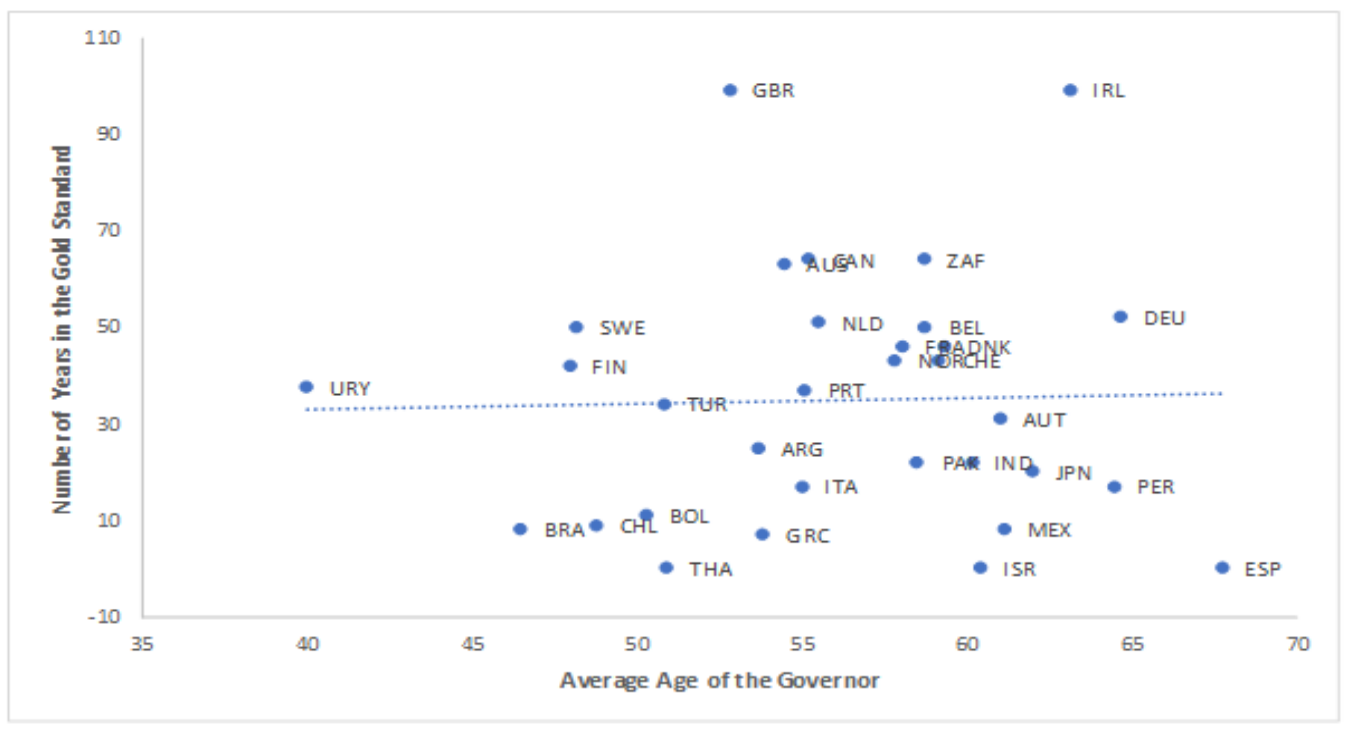

Overall, we find that institutional memory and personal experience are not mutually exclusive. Yet, among countries that had been exposed to the gold standard, the experience of policymakers has more predictive power than the number of years spent in the gold standard. The age of the governor, however, might be associated with other institutional characteristics that we have some difficulties to capture with the number of years, such as the reaction of the central bank to the end of the gold standard in the 1930s, as illustrated by our Swedish and Belgium cases. In

\footnotetext{
${ }^{30}$ Since the variable "age" has mechanically a unit root in countries where the governors changed unfrequently, we use the average age of governors over the period, as plotted in Figure 3.
} 
that case, the fact that the age of the governor tends to dominate our "institutional memory" proxies might simply reflect other effects of corporate culture which are not captured by the length of the gold standard experience. Even if it is the case, however, it is still fully consistent with our argument that memory matters, in one form or another, to shape current policies.

Table 3: Personal Experience and Institutional Memory

\begin{tabular}{lccc}
\hline VARIABLES & $(1)$ & $(2)$ & $(3)$ \\
\hline & & & \\
Trade & -0.000563 & -0.0112 & $-0.0340^{* *}$ \\
& $(0.00884)$ & $(0.00965)$ & $(0.0138)$ \\
Currency & -0.652 & -0.652 & $-2.766^{* * *}$ \\
& $(0.419)$ & $(0.430)$ & $(0.579)$ \\
Gold Standard Exposure & & $-3.195^{* * *}$ & -0.0121 \\
& & $(0.610)$ & $(0.02)$ \\
Currency x Gold Standard Exposure & & $0.433^{\star * *}$ & 0.00432 \\
& & $(0.0716)$ & $(0.003)$ \\
Age of Governor & $-0.329^{* * *}$ & $-0.268^{* * *}$ & $-0.488^{* * *}$ \\
& $(0.0582)$ & $(0.0581)$ & $(0.0782)$ \\
Currency x Age of Governor & $0.0193^{* * *}$ & $0.0149^{* *}$ & $0.0520^{* * *}$ \\
& $(0.00748)$ & $(0.00749)$ & $(0.0111)$ \\
Country FE & & & \\
Time FE & No & No & No \\
Controls & Yes & Yes & Yes \\
Observations & Yes & Yes & Yes \\
R-squared & 617 & 617 & 445 \\
\hline
\end{tabular}

Note: P-value in parentheses. ${ }^{* * *},{ }^{* *},{ }^{*}$ denote significance at the $1 \%, 5 \%, 10 \%$ levels. Results are based on Equation (2) in the text. All estimations are derived in a pooled panel. Year-fixed effects are included in all estimations. Control variables are the same as in Table 1. Columns (1) and (2) use the full sample for which information on the age of the governor is available. In column (2), th gold standard exposure is a dummy variable which takes the value 1 if the country adhered to both the classical and interwar gold standards. Column (3) restricts attention to gold standard countries and exposure is measured by the number of years a country adhered to the gold standard.

\section{Extensions and Robustness}

\section{Alternative Dependent Variables}

The results of the previous section have shown that monetary authorities continued to use gold to back currency in circulation, and that they were more likely to do so if they had been in the gold standard before. Was it specific to gold reserves? Can we interpret our results in terms of 
a portfolio choice, and relate them to the behavioral finance literature (e.g. Malmendier and Nagel 2011, 2015; Koudijs and Voth 2016)? Estimations in Table 4 address this question. We still find a significant and positive - but smaller - coefficient on currency/GDP when non-gold reserves (i.e. foreign exchange) are the dependent variable. However, it is not robust if we include country-fixed effects (Table 4, column 5). In contrast, we find a strong, significant and robust coefficient on currency/GDP when the share of gold in total foreign reserves (goldshare) is used as the dependent variable (Table 4, columns 3-4, 6). In the pooled panel, the interaction term of gold standard exposure*currency is negative for non-gold reserves (column 2) and positive for the gold share (column 4). Overall, those results confirm that monetary authorities treated gold and foreign exchange reserves differently, and that the allocation between the two forms of reserves was driven more by the persistence of past behavior rather than purely financial considerations. They also provide definitive evidence that gold and foreign exchange were not perfect substitutes under the Bretton Woods system, a point with important policy implications that we develop in section VI. Finally, the findings can be seen as a "placebo test" which shows that the results of the previous sections (Tables 1-3) were specific to gold and not driven by important omitted factors that would be common to all foreign reserves. This is true for the (non) sterilization of foreign reserve interventions, to which we now turn our attention.

Table 4: Determinants of Non-Gold Reserves and Share of Gold in Total Reserves

\begin{tabular}{|c|c|c|c|c|c|c|}
\hline VARIABLES & $\begin{array}{c}\text { Non-Gold } \\
\text { Reserves } \\
\text { (1) } \\
\end{array}$ & $\begin{array}{c}\text { Non-Gold } \\
\text { Reserves } \\
\text { (2) }\end{array}$ & $\begin{array}{c}\text { Gold } \\
\text { Share } \\
(3) \\
\end{array}$ & $\begin{array}{c}\text { Gold } \\
\text { Share } \\
(4) \\
\end{array}$ & $\begin{array}{c}\text { Non-Gold } \\
\text { Reserves } \\
(5)\end{array}$ & $\begin{array}{c}\text { Gold } \\
\text { Share } \\
(6) \\
\end{array}$ \\
\hline Trade & $\begin{array}{l}0.0334^{* * *} \\
(0.00731)\end{array}$ & $\begin{array}{l}0.0355^{\text {***}} \\
(0.00733)\end{array}$ & $\begin{array}{l}-0.179^{\star * *} \\
(0.0742)\end{array}$ & $\begin{array}{l}-0.196^{\text {***}} \\
(0.0736)\end{array}$ & $\begin{array}{l}0.105^{* \star *} \\
(0.0247)\end{array}$ & $\begin{array}{c}0.111 \\
(0.262)\end{array}$ \\
\hline Currency & $\begin{array}{c}0.0985^{\star * *} \\
(0.0268)\end{array}$ & $\begin{array}{l}0.204^{* * *} \\
(0.0458)\end{array}$ & $\begin{array}{c}1.398^{* \star *} \\
(0.240)\end{array}$ & $\begin{array}{c}0.508 \\
(0.385)\end{array}$ & $\begin{array}{l}-0.247^{\star \star *} \\
(0.112)\end{array}$ & $\begin{array}{l}2.269^{* *} \\
(0.910)\end{array}$ \\
\hline Gold Stan dard & $\begin{array}{c}-1.298^{*-*} \\
(0.264)\end{array}$ & $\begin{array}{c}0.199 \\
(0.391)\end{array}$ & $\begin{array}{c}9.438^{* \kappa *} \\
(1.886)\end{array}$ & $\begin{array}{l}-3.243 \\
(4.074)\end{array}$ & & \\
\hline Currency x Gold Standard & & $\begin{array}{c}-0.198^{\star \star *} \\
(0.0552)\end{array}$ & & $\begin{array}{c}1.679^{* * *} \\
(0.459)\end{array}$ & & \\
\hline Country FE & No & No & No & No & Yes & Yes \\
\hline Time FE & Yes & Yes & Yes & Yes & Yes & Yes \\
\hline Controls & Yes & Yes & Yes & Yes & Yes & Yes \\
\hline Observations & 729 & 729 & 728 & 728 & 729 & 728 \\
\hline R-squared & 0.282 & 0.295 & 0.301 & 0.313 & 0.368 & 0.173 \\
\hline
\end{tabular}

Note: P-value in parentheses. ${ }^{* * *},{ }^{* *},{ }^{*}$ denote significance at the $1 \%, 5 \%, 10 \%$ levels. Control variables are the same as in Table 1. Columns (1) to (4) report results of pooled panel estimations. Country-fixed effects are used in columns (5) and (6), with standard errors clustered at the country level. 


\section{Reverse Causality and Sterilization}

As emphasized in Obstfeld et al. (2010), there could be reverse causality between reserves and currency in circulation if there is incomplete sterilization (although the authors provide convincing evidence that it is not a problem in their post Bretton Woods sample). Heller (1976) was one of the first to discuss this potential endogeneity bias. A country may increase its money supply to buy reserves. If this is not fully sterilized, it creates a positive correlation between foreign reserves and currency. Sterilization of foreign exchange interventions is and was a common practice of central banks during Bretton Woods (Obstfeld 1980, Naef 2017, Monnet 2018b) because they usually wanted to avoid that the size of their balance sheet and the money supply be determined by the exchange rate. But, we cannot rule out the possibility that it was incomplete. This reverse causality issue, however, is more likely to be severe at higher frequencies (monthly, quarterly) when full sterilization is not always possible. A significant reverse causality bias at the annual frequency would mean that countries allowed their domestic money supply to be mainly influenced by their exchange rate policy. In that case, controlling for current account surplus and exchange rate misalignment (exchange rate premium) would lower the potential omitted variable bias. More importantly, simultaneity issues due to imperfect sterilization are much more likely to be a concern for foreign exchange reserves because central banks did not use gold to intervene on foreign exchange markets. ${ }^{31}$ Facing an inflow of capital, banks could exchange foreign currency at the central bank against domestic currency, thereby increasing the foreign assets of the central bank and, if not fully sterilized, the domestic currency in circulation. Since gold was not used as a means of payment for private commercial and financial transactions however, this mechanism does not apply to gold reserves. ${ }^{32}$

\section{Implications: New Perspectives on the Bretton Woods system}

Triffin (1960) famously claimed that the Bretton Woods system was doomed to failure because of a fundamental dilemma (later called the "Triffin dilemma"): expanding the volume of foreign reserves held in dollar would diminish the US credibility, whereas restricting dollar issuance would push the world in a deflationary spiral. It followed from this argument that the fixed gold-dollar parity was unsustainable because the US had to issue too many dollars to follow the expansion of international trade. Triffin's view was challenged by other economists arguing that the system could function with the US keeping a thin film of gold, because US short-term liabilities financed investment that was beneficial for the world (Despres, Kindleberger \& Salant 1966, McKinnon 1969; see Farhi \& Maggiori 2017, Bordo \& McCauley 2018, Gourinchas et al. 2019 for recent discussions of these debates). After the collapse of the Bretton Woods system, it

\footnotetext{
31 The only exception were interventions by the United States (and then by the Gold Pool) to stabilize the dollar price of gold on the London gold market (Bordo et al. 2017).

${ }^{32}$ It is possible that, facing an increase in the domestic money supply due to international capital flows, the monetary authorities decide to increase their gold reserves to back the money supply. This phenomenon is not an endogeneity bias however, but a deliberate policy of the central bank to back money supply with gold.
} 
became obvious that the dollar did not need to be backed by gold to remain the leading international currency. Although Triffin's views were ultimately proven wrong, his views were very influential and epitomized the persistence of a gold standard mentality. Our results suggest that foreign monetary authorities around the world did not give up references to the gold standard' norms and never treated the dollar and gold as perfect substitutes, despite the original intentions of its founders and numerous schemes of central bank cooperation (James 1996, Schenk 2010, Bordo, Monnet and Naef 2017). Ultimately, the old habits of the central bankers prevented the Bretton Woods system to function as expected.

This does not mean, however, that our results should be interpreted in a purely deterministic way. Central bank habits do not persist independently of the historical context. As argued by McKinnon (1969) and Bordo and McCauley (2018), the international role of the dollar might have been maintained without breaking the convertibility of US gold reserves if US policies had been fully credible in the 1960s. Likewise, it is easy to conjecture, for example, that gold standard practices could have disappeared if the US had not been required to hold gold reserves by the 1944 Bretton Woods agreement. Accordingly, such practices eventually disappeared after the link between the dollar and US gold reserves was abandoned in August 1971, and world inflation made it impossible for the gold supply to follow the expansion of the money base in the subsequent years (Figure 4).

Figure 4: Currency-Gold Correlation (1950-1973)

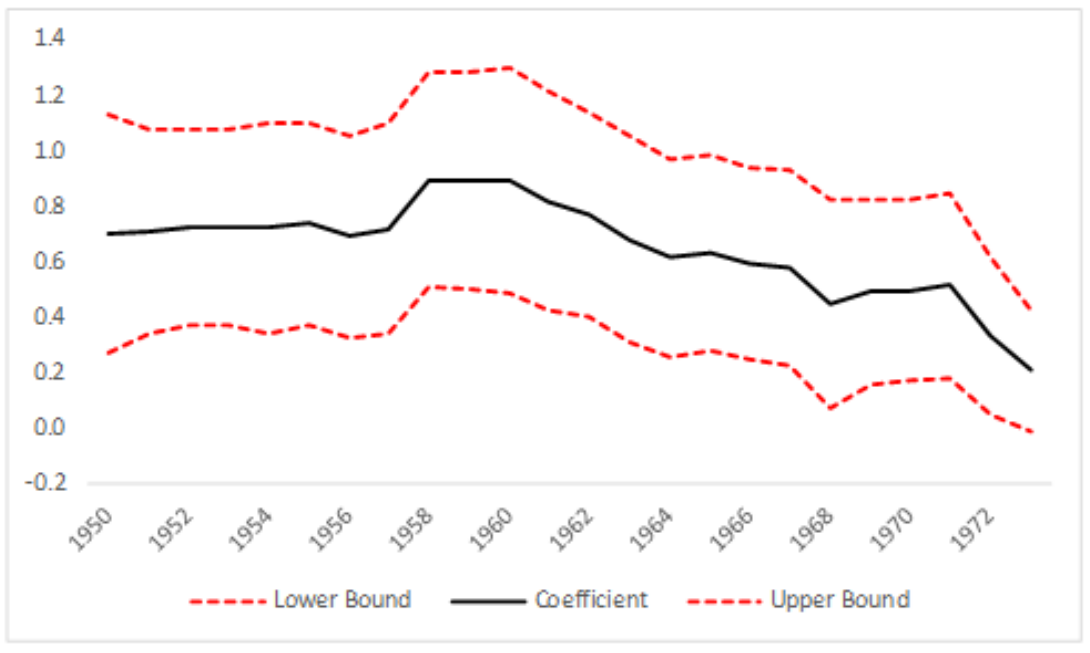

Note: The correlation between gold reserves (over GDP) and currency (over GDP) is computed using the sample of countries which have been in both the classical and interwar gold standards and over 5- year rolling windows. 


\section{Conclusion}

It is commonly assumed that the history of business or policy organizations shape their current behavior. Past experiences of hyperinflation are used, at least anecdotally, to rationalize the aversion against price instability of central banks. Business history has provided many examples of the strength of corporate culture though case studies (Lipartito 1995). A recent literature in corporate finance gives statistical evidence that managerial traits relate to corporate outcomes (Bertrand and Schoar 2003, Malmendier et al. 2011, Benmelech \& Frydman 2015). However, quantitative evidence on the macroeconomic effects of both corporate culture and individual experience of policymakers is missing.

This paper argues that the postwar international monetary system would have functioned differently if monetary authorities had not followed practices inherited from their past. Central banks under Bretton Woods still tied their hands by backing money supply with gold reserves (although devaluation remained an option, contrary to the gold standard). This is consistent with some accounts of contemporary central bankers (Holtrop 1957) as well as with some recent research which has shown that - contrary to a widely held view - inflation stabilization was a key objective of central bank in the 1950s and 1960s, well before the Great Inflation of the 1970s (Romer and Romer 2002, Monnet 2014, 2018a). Thus, this paper reopens the debate about the potential impact of the end of the Bretton Woods system on monetary policy in the 1970s, and on the global consequences of the institutional turn to fiat money. Given the persistent role of gold in 1950-1960, the demise of the Bretton Woods system indeed led to the loss of an anchor for central banks. More generally, our findings call for further research on how the history of central banks still shape their current monetary policy. 


\section{Data appendix}

We use standard and well-established data sources for control variables, GDP and trade. All data are annual. The foreign reserve data (gold and non-gold) are taken from International Financial Statistics (IFS) published by the International Monetary Fund. According to the Bretton Woods agreement, countries had to provide such data to the IMF. The IMF was in charge of building a coherent and harmonized definition of foreign reserves across countries. Reserve data cover all monetary authorities (central bank, treasury and any other parastatal organization which had a role in foreign exchange intervention on the behalf of the State).$^{33}$ Monetary statistics are also taken from IFS. Series of money are also published in Mitchell (2013) with the distinction between banknotes (i.e. currency in circulation) and total M1 (banknotes, short-term deposits with the central bank and other monetary institutions). Given data limitations for the Bretton Woods period, we use M1 instead of M2. M1 does not include long-term deposits.

A tedious task has been to convert all nominal values in the domestic currency of 1971, such that we can have comparable ratios across countries. Since foreign reserves are expressed in US dollars, we use exchange rates from IMF statistics (end of the year) to convert them. Monetary statistics are expressed in the domestic currency of the contemporaneous year (in many countries the currency has changed over time). Nominal GDP and trade data from Penn World Table are expressed in domestic currency of 2014. To obtain comparable values, we track changes in currency denomination using paper volumes of the International Financial Statistics published monthly since 1946 and converted all values in the domestic currency of 1971. Overall, our sample covers 38 countries, for a total of 729 observations. ${ }^{34}$

\footnotetext{
${ }^{33}$ Kenen (1963) and Naef (2017) highlight that some countries used various techniques to misreport their holding of foreign exchange reserves (although such practice should have led to IMF sanctions). As far as we are aware, such misreporting happened only for foreign exchange reserves. For instance, the Bank of England would report a higher level of foreign exchange by swapping dollars with the US Federal Reserve days before the publication of its balance sheet.

${ }^{34}$ Due to some remaining irregular gaps in the data (especially monetary statistics in the early 1950s), our sample includes 729 observations rather than 798. For nine additional countries, we collected statistics on money, reserves, trade and GDP but were not able to have all the control variables. Results are similar if these countries are included in the estimations.
} 
TABLE A.1: SAMPLE AND DESCRIPTIVE STATISTICS

\begin{tabular}{|c|c|c|c|c|c|c|}
\hline Countries & $\begin{array}{l}\text { Years in the } \\
\text { gold standard }\end{array}$ & $\begin{array}{l}\text { Years in the gold } \\
\text { standard as } \\
\text { independent } \\
\text { countries }\end{array}$ & $\begin{array}{l}\text { Gold Share } \\
\text { (mean, in } \\
\text { percent) }\end{array}$ & $\begin{array}{l}\text { Reserves/GDP } \\
\text { (mean, in } \\
\text { percent) }\end{array}$ & $\begin{array}{c}\text { Gold } \\
\text { Reserves/GDP } \\
\text { (mean, in } \\
\text { percent) }\end{array}$ & $\begin{array}{c}\text { Currency/GDP } \\
\text { (mean, in } \\
\text { percent) }\end{array}$ \\
\hline ARG & 25 & 25 & 41 & 2 & 1 & 9 \\
\hline AUS & 63 & 0 & 12 & 7 & 1 & 5 \\
\hline AUT & 31 & 31 & 34 & 10 & 4 & 11 \\
\hline BEL & 50 & 50 & 66 & 13 & 8 & 20 \\
\hline BOL & 11 & 11 & 33 & 2 & 1 & 6 \\
\hline BRA & 8 & 8 & 44 & 3 & 1 & 6 \\
\hline CAN & 64 & 0 & 38 & 6 & 2 & 5 \\
\hline CHE & 43 & 43 & 79 & 26 & 20 & 17 \\
\hline CHL & 9 & 9 & 47 & 2 & 1 & 4 \\
\hline CRI & 18 & 18 & 14 & 3 & 0 & 5 \\
\hline DEU & 52 & 52 & 37 & 6 & 2 & 6 \\
\hline DNK & 46 & 46 & 26 & 4 & 1 & 6 \\
\hline ECU & 21 & 21 & 42 & 4 & 2 & 5 \\
\hline EGY & 36 & 0 & 49 & 10 & 3 & 17 \\
\hline ESP & 0 & 0 & 57 & 4 & 2 & 11 \\
\hline FIN & 42 & 42 & 17 & 4 & 1 & 4 \\
\hline FRA & 46 & 46 & 71 & 4 & 3 & 12 \\
\hline GBR & 96 & 96 & 67 & 4 & 3 & 8 \\
\hline GRC & 7 & 7 & 21 & 5 & 1 & 8 \\
\hline IND & 22 & 0 & 28 & 3 & 1 & 11 \\
\hline IRL & 99 & 0 & 5 & 19 & 1 & 10 \\
\hline ISR & 0 & 0 & 5 & 9 & 1 & 7 \\
\hline ITA & 17 & 17 & 48 & 6 & 3 & 11 \\
\hline JPN & 20 & 20 & 9 & 4 & 0 & 8 \\
\hline KOR & 0 & 0 & 1 & 5 & 0 & 5 \\
\hline MEX & 8 & 8 & 33 & 3 & 1 & 4 \\
\hline NIC & 17 & 17 & 11 & 3 & 0 & 3 \\
\hline NLD & 51 & 51 & 65 & 13 & 9 & 11 \\
\hline NOR & 43 & 43 & 14 & 6 & 1 & 10 \\
\hline PAK & 22 & 0 & 19 & 5 & 1 & 16 \\
\hline PER & 17 & 17 & 42 & 4 & 2 & 6 \\
\hline PRT & 37 & 37 & 61 & 23 & 14 & 14 \\
\hline PRY & 0 & 0 & 4 & 2 & 0 & 6 \\
\hline SWE & 50 & 50 & 30 & 4 & 1 & 8 \\
\hline THA & 0 & 0 & 23 & 15 & 3 & 11 \\
\hline TUR & 34 & 34 & 60 & 3 & 1 & 6 \\
\hline URY & 40 & 40 & 85 & 9 & 7 & 6 \\
\hline $\mathrm{ZAF}$ & 64 & 0 & 64 & 7 & 4 & 5 \\
\hline
\end{tabular}




\section{References}

Aizenman J. \& Lee L., (2008). Financial versus Monetary Mercantilism: Long-run View of Large International Reserves Hoarding. The World Economy, 31(5), pages 593-611, 05

Aizenman, J., \& Inoue, K. (2013). Central banks and gold puzzles. Journal of the Japanese and International Economies, 28, 69-90.

Alesina, A., \& Fuchs-Schündeln, N. (2007). Goodbye Lenin (or not?): The effect of communism on people's preferences. American Economic Review, 97(4), 1507-1528.

Aufricht, H. (Ed.). (1967). Central Banking Legislation: A Collection of Central Bank, Monetary, and Banking Laws, volume 2, International Monetary Fund.

Bazot, G., Bordo, M. D., \& Monnet, E. (2016). International shocks and the balance sheet of the Bank of France under the classical gold standard. Explorations in Economic History, 62, 87-107.

Benmelech, E., \& Frydman, C. (2015). Military CEOs. Journal of Financial Economics, 117(1), 43-59.

Bertrand, M., \& Schoar, A. (2003). Managing with style: The effect of managers on firm policies. The Quarterly journal of economics, 118(4), 1169-1208.

Bordo M.D, (1993). The Bretton Woods International Monetary System: A Historical Overview, in A Retrospective on the Bretton Woods System, edited by Michael D. Bordo and Barry Eichengreen, pp. 3-98. Chicago: University of Chicago Press,

Bordo M. D. \& Eichengreen B. ed. (1993). A Retrospective on the Bretton Woods System. Chicago: University of Chicago Press.

Bordo M. D. \& Eichengreen B. (1998). The Rise and Fall of a Barbarous Relic: The Role of Gold in the International Monetary System. (No. w6436). National Bureau of Economic Research.

Bordo, M. D., \& McCauley, R. N. (2018). Triffin: dilemma or myth? (No. w24195). National Bureau of Economic Research.

Bordo, M., Monnet, E., \& Naef, A. (2017). The Gold Pool (1961-1968) and the Fall of the Bretton Woods System. Lessons for Central Bank Cooperation (No. w24016). National Bureau of Economic Research.

Bordo, M. D., \& Istrefi, K. (2018). Perceived FOMC: The Making of Hawks, Doves and Swingers (No. w24650). National Bureau of Economic Research.

Bouwman, C. H., \& Malmendier, U. (2015). Does a Bank's History Affect Its Risk-Taking? American Economic Review, 105(5), 321-25.

Camerer, C. \& Malmendier, U. (2007). Behavioral economics of organizations. In Behavioral Economics and Its Applications, edited by P.Diamond and H. Vartiainen, p. 235-290, Princeton: Princeton University Press,

Capie, F. (2010). The Bank of England: 1950s to 1979. Cambridge: Cambridge University Press.

Cassiers, I., \& Ledent, P. (2006). Learning to manage external constraints: Belgian monetary policy during Bretton-Woods era (1944-1971). IRES Discussion Paper, 2006/032.

Cohen, B.J (1975). International reserves and liquidity. In International Trade And Finance, edited by P. B. Kenen, p.1-52. Cambridge: Cambridge University Press. 
Courchene, T.J., \& G. M. Youssef, (1967). The demand for international reserves. The Journal of Political Economy, 75(4), 404-413.

Despres, E., Kindleberger, C. P., \& Salant, W. S. (1966). The dollar and world liquidity: a minority view. Washington DC: Brookings Institution.

Eichengreen, B., \& Temin, P. (2000). The gold standard and the great depression. Contemporary European History, 9(2), 183-207.

Eichengreen, B., Mehl, A., \& Chitu, L. (2017). How Global Currencies Work: Past, Present, and Future. Princeton: Princeton University Press.

Farhi, E., \& Maggiori, M. (2017). A Model of the International Monetary System. The Quarterly Journal of Economics, 133(1), 295-355.

Frère, M. (1960). La restauration monétaire de la Belgique. Revue d'économie politique, 70(6), $82-108$.

Gennaioli, N., \& Shleifer, A. (2010). What comes to mind. The Quarterly journal of economics, 125(4), 1399-1433.

Gilbert, M. (1968). The Gold-Dollar system: conditions of equilibrium and the price of gold (Vol. 70). International Finance Section, Dept. of Economics, Princeton University.

Gourinchas, P. O., Rey, H., \& Sauzet, M. (2019). The International Monetary and Financial System (No. w25782). National Bureau of Economic Research.

Grubel, H.G (1971). The demand for international reserves: a critical review of the literature. Journal of Economic Literature, 9(4): 1148-1166.

Helleiner, E. (2014). Forgotten foundations of Bretton Woods: International development and the making of the postwar order. Ithaca: Cornell University Press.

Heller, H.R. (1976). International Reserves and World-Wide Inflation. Staff Papers-International Monetary Fund, 23(1), 61-87.

Holtrop, M.W. (1957). Method of monetary analysis used by the Nederlandsche Bank. Staff Papers-International Monetary Fund, 5(3), 303-316.

Horsefield, K., ed. (1969). The International Monetary Fund, 1945-1965: Twenty Years of International Monetary Co-Operation. Vol. 3, Washington, D.C.: International Monetary Fund.

James, H., (1985). The Reichsbank and Public Finance in Germany, 1924-1933: A Study of the Politics of Economics during the Great Depression (Schriftenreihe des Instituts für Bankhistorische Forschung, number 5.) Frankfurt a/M: Fritz Knapp

James, H., (1996). International Monetary Cooperation Since Bretton Woods. Washington DC: Oxford University Press \& IMF.

Jeanne, O., \& Rancière, R. (2011). The optimal level of international reserves for emerging market countries: a new formula and some applications. The Economic Journal, 121(555), 905930.

Jeanne, O., \& Sandri, D. (2016). Optimal reserves in financially closed economies (No. w22139). National Bureau of Economic Research.

Jonung, L. (1979). Knut Wicksell's norm of price stabilization and Swedish monetary policy in the 1930's. Journal of Monetary Economics, 5(4), 459-496.

International Monetary Fund (IMF), 1971, International Reserves. Needs and Availability, Papers 
and Proceedings. Seminar at the International Monetary Fund, Washington DC.

Kenen, P. B. (1963). Reserve-asset preferences of central banks and stability of the gold-exchange standard (No. 10). International Finance Section, Dept. of Economics, Princeton University.

Kenen, P.B., \& Yudin E.B. (1965). The demand for international reserves. The Review of Economics and Statistics, 242-250.

Koudijs, P., \& Voth, H. J. (2016). Leverage and beliefs: personal experience and risk-taking in margin lending. American Economic Review, 106(11), 3367-3400.

Kriz, M. A. (1959). Gold in world monetary affairs today (No. 34). International Finance Section, Dept. of Economics, Princeton University.

Kriz, M. A. (1967). Gold: barbarous relic or useful instrument? (No. 60). International Finance Section, Dept. of Economics, Princeton University.

Larsson, M., \& Söderberg, G. (2017). Finance and the Welfare State: Banking Development and Regulatory Principles in Sweden, 1900-2015. Springer.

Lipartito, K. (1995). Culture and the practice of business history. Business and Economic History, 24(2), 1-41.

Machlup, F. (1964). Plans for the Reform of the International Monetary System. Princeton Essays in International Economics, $\mathrm{n}^{\circ} 3$ Princeton University, International Finance Section.

Machlup, F. (1966), The need for monetary reserves. PSL Quarterly Review 19-78.

Makin, J. H., 1971, The composition of international reserve holdings: A problem of choice involving risk. American Economic Review 61(5), 818-832.

Malmendier, U., \& Nagel, S. (2011). Depression babies: do macroeconomic experiences affect risk taking? The Quarterly Journal of Economics, 126(1), 373-416.

Malmendier, U., Tate, G., \& Yan, J. (2011). Overconfidence and early life experiences: the effect of managerial traits on corporate financial policies. The Journal of finance, 66(5), 16871733.

Malmendier, U., \& Nagel, S. (2015). Learning from inflation experiences. The Quarterly Journal of Economics, 131(1), 53-87.

Malmendier, U., Nagel, S., \& Yan, Z. (2017). The making of hawks and doves: Inflation experiences on the FOMC (No. w23228). National Bureau of Economic Research.

McKinnon, R. I. (1969). Private and Official International Money: The Case for the Dollar. Princeton Essays in International $\mathrm{n}^{\circ} 74$, Economics. Princeton University, International Finance Section.

Mishra, P., \& Reshef, A. (2019). How Do Central Bank Governors Matter? Regulation and the Financial Sector. Journal of Money, Credit and Banking, vol. 51, $\mathrm{n}^{\circ} 2-3$.

Mitchener, K. J., \& Weidenmier, M. D. (2015). Was the classical gold standard credible on the periphery? Evidence from currency risk. The Journal of Economic History, 75(2), 479511.

Monnet, E. (2014). Monetary policy without interest rates: Evidence from France's Golden Age (1948 to 1973) using a narrative approach. American Economic Journal: Macroeconomics 6 ( 4$), 137-169$.

Monnet, E. (2018a), Controlling Credit. Central banking and the planned economy in postwar 
France, 1948-1973, Cambridge University Press.

Monnet, E. (2018b). Credit controls as an escape from the trilemma. The Bretton Woods experience. European Review of Economic History, 22(3), 349-360.

Mouré, K. (2002). The Gold Standard Illusion: France, the Bank of France, and the International Gold Standard, 1914-1939. Oxford: Oxford University Press.

Naef, A. (2017). Dirty float or clean intervention? The Bank of England on the foreign exchange market, 1952-72. University of Cambridge Mimeo.

Obstfeld, M. (1980). Sterilization and offsetting capital movements: Evidence from West Germany, 1960-1970. (No. w494). National Bureau of Economic Research.

Obstfeld, M., \& Taylor, A. M. (2004). Global capital markets: integration, crisis, and growth. Cambridge University Press.

Obstfeld, M., Shambaugh J.C, \& Taylor, A.M (2010). Financial Stability, the Trilemma, and International Reserves. American Economic Journal: Macroeconomics 2(2) , 57-94.

Officer, L. H., \& Willett T.D, (1969). Reserve-asset preferences and the confidence problem in the crisis zone. The Quarterly Journal of Economics, 83(4), 688-695.

Officer, L. H. (2008). Gold standard, EH. net encyclopedia. http://eh. net/encyclopedia/article/officer. gold. standard.

Penn Word Table: Feenstra, Robert C., Robert Inklaar and Marcel P. Timmer (2013), "The Next Generation of the Penn World Table" available for download at www.ggdc.net/pwt

Quinn, D. P. \& Toyoda A.M. (2008). "Does Capital Account Liberalization Lead to Economic Growth?", Review of Financial Studies, 21(3):1403-1449.

Rathke, A., Straumann, T., \& Woitek, U. (2017). Overvalued: Swedish monetary policy in the 1930s. International Economic Review, 58(4), 1355-1369.

Reinhart C.M. \& Rogoff K.S (2004). The Modern History of Exchange Rate Arrangements: A Reinterpretation. The Quarterly Journal of Economics. 119(1), pages 1-48, February.

Rodrik, D. (2006). The Social Cost of Foreign Exchange Reserves. International Economic Journal, 20(3): 253-66

Romer, C. D., \& Romer, D. H. (2002). A Rehabilitation of Monetary Policy in the 1950's. American Economic Review, 92(2), 121-127.

Romer, C. D., \& Romer, D. H. (2004). Choosing the Federal Reserve chair: lessons from history. Journal of Economic Perspectives, 18(1), 129-162.

Rowlinson, M., \& Procter, S. (1999). Organizational culture and business history. Organization Studies, 20(3), 369-396.

Schenk, C. R. (2010). The decline of sterling: managing the retreat of an international currency, 1945-1992. Cambridge: Cambridge University Press.

Schuler \& Rosenberg (2012), "The Bretton Woods Transcripts", Center for Financial Stability, Paper in Financial History, New York.

Schuler \& Rosenberg (2014), "Who was at Bretton Woods", Center for Financial Stability, Paper in Financial History, New York.

Scott-Smith, G., \& Rofe, J. S. (Eds.). (2017). Global Perspectives on the Bretton Woods Conference and the Post-War World Order. Springer.

Straumann, T. (2010). Fixed ideas of money: Small states and exchange rate regimes in twentieth- 
century Europe. Cambridge; Cambridge University Press.

Straumann, T., Kugler, P., \& Weber, F. (2017). How the German crisis of 1931 swept across Europe: a comparative view from Stockholm. The Economic History Review, 70(1), 224247.

Triffin, R. (1960). Gold and the Dollar Crisis. New Haven, Conn.: Yale University Press.

Van der Wee, H. (2012). "Belgian Monetary Policy under the Gold Standard during the Interwar Period". In The Gold Standard Peripheries (pp. 130-144). Palgrave Macmillan, London.

Wandschneider, K. (2008). The stability of the interwar gold exchange standard: Did politics matter? The Journal of Economic History, 68(1), 151-181.

Wellens, R. (1976). Inventaire des papiers de Maurice Frère, gouverneur de la Banque nationale de Belgique. Archives générales du Royaume de Belgique.

Williamson, J. (1973). Surveys in applied economics: International liquidity. Economic Journal 83(3), 685-746 